\title{
Presence of an aromatase inhibitor, possibly heat shock protein 90, in dominant follicles of cattle
}

\author{
M. A. Driancourt ${ }^{1}$, P. Guet ${ }^{1}$, K. Reynaud ${ }^{1}$, A. Chadli ${ }^{2}$ and M. G. Catelli ${ }^{2}$ \\ ${ }^{1}$ INRA, PRMD, 37380 Monnaie, France; and ${ }^{2}$ INSERM U 33, 94276 Le Kremlin Bicetre, France
}

\begin{abstract}
In cattle, it has been suggested that follicular fluid has direct modulatory effects on follicular growth and maturation. In the first part of this study, an in vitro test using aromatase activity of follicular wall fragments as an end point was validated for cattle follicles and was used to test whether follicular fluid (from dominant or non-dominant follicles) modulates aromatase activity. Fluid from dominant follicles at a concentration of 24 or $12 \%$ (obtained during the luteal and follicular phases, respectively) significantly inhibited aromatase activity. Inhibitory activity was low or absent in fluid from nondominant follicles. FSH-stimulated aromatase activity was also reduced by fluid from dominant follicles, but not to a greater extent than in basal conditions. Finally, charcoaltreated fluid from dominant follicles retained its inhibitory activity. In contrast, ovarian venous serum draining a dominant follicle had no activity at the three concentrations tested $(6,12$ and $24 \%)$. In the second part of the study, identification of the compounds involved in this modulatory activity was attempted using SDS-PAGE. Comparison of the fluorographs from de novo synthesized proteins stored in follicular fluid (inhibitory medium) with those secreted in incubation medium (inactive medium) demonstrated that one protein $(90 \mathrm{kDa}, \mathrm{pI} 5.8)$ was significantly $(P<0.05)$ more abundant in fluid from dominant follicles $(2.0 \pm 0.09 \%)$ than in the culture medium $(1.3 \pm 0.1 \%$ of the total proteins). This protein had characteristics similar to those of heat shock protein 90 (hsp 90). Therefore, in the final part of the study, the presence of hsp 90 in ovarian cells and follicular fluid was investigated using immunohistochemistry and western blot analysis. After immunohistochemistry, a positive signal was detected mainly in the granulosa cells of larger follicles and to a smaller extent in thecal cells and oocytes. Western blot analysis also demonstrated the presence of hsp 90 in follicular wall fragments and fluid. When blotting was achieved on a sample of follicular fluid resolved by two-dimensional PAGE, the spot detected had a similar location to that at $90 \mathrm{kDa}$ and $\mathrm{pI}$ 5.8. Addition of purified hsp 90 to bovine follicles in vitro depressed aromatase activity by altering the $K_{m}$ value (and possibly the $V_{\max }$ value) of the enzyme. It is proposed that hsp 90 is a functional regulator of follicular maturation through its action on aromatase.
\end{abstract}

\section{Introduction}

In cattle, growth and maturation of a large presumptive ovulatory follicle is associated with regression of the other follicles in the cohort of recruited follicles (Pierson and Ginther, 1988; Savio et al., 1988; Sirois and Fortune, 1988; Fortune et al., 1991). The mechanisms involved in the induction of atresia in the smaller follicles of the cohort, and in the survival and maturation of the dominant follicle in an environment that is hostile to the other follicles have not been clarified. There is clear evidence from superovulation that FSH administration can override follicular dominance, suggesting that FSH plays a key role in the control of these events.

Revised manuscript received 3 August 1998.
However, in humans ovarian factors secreted by the dominant follicle have a modulatory role in induction of atresia of the smaller follicles (di Zerega et al., 1982). In addition, in pigs, factors in the fluid of the dominant follicle may affect its survival (Ledwitz Rigby, 1983). Compounds that affect cell replication and steroid production have been identified in the follicular fluid of cattle (Baxter et al., 1995; Rouillier et al., 1998), but the relationship between follicular dominance and the presence of these compounds has not been addressed. Hence, the initial aims of this study were: (i) to determine whether the fluid of dominant follicles affects the aromatase activity of bovine follicles in basal and FSH-stimulated conditions; and (ii) to determine whether any effects on aromatase activity could also be detected in ovarian venous blood draining the dominant follicle. 
Follicular fluid is a complex mixture of steroids, growth factors and proteins produced by ovarian cells and serum borne growth factors and proteins. In vitro studies with specific growth factors (insulin-like growth factor I (IGF-I), transforming growth factor $\alpha$ (TGF- $\alpha$ ); Monget and Monniaux, 1995; Scaramuzzi and Downing, 1995) and proteins (inhibin, IGF binding protein (IGFBP); Ying et al., 1986; Ui et al., 1989) have demonstrated that many of these compounds have physiological effects on ovarian cells. However, it is not clear whether these factors are responsible for the effects of follicular fluid on follicular growth in cattle (Law et al., 1992; Wood et al., 1993). Hence, the additional objectives of this study were: (iii) to compare the patterns of proteins stored in follicular fluid (that is, involved in follicle regulation) with those secreted outside the follicle using twodimensional PAGE; and (iv) to identify the main compound differing between these two fluids by two-dimensional western blotting, and confirm its presence in the ovary by immunohistochemistry and western blotting.

\section{Materials and Methods}

\section{Collection of serum and follicular fluid}

Ten cyclic 3-4-year-old heifers were examined for oestrus once a day with a vasectomized bull. During the second half of the luteal phase, all animals were synchronized by a single injection of a prostaglandin analogue (Prosolvin, $1 \mathrm{ml}$ i.m.; Intervet, Angers).

Starting at the time of luteolysis, ultrasound examination was carried out once a day to monitor growth of the dominant follicle and identify on which ovary (left or right) it was developing. At $48 \mathrm{~h}$ after administration of prostaglandin, all heifers were anaesthetized by injection of $5 \mathrm{~g}$ sodium thiopentone (Rhone Poulenc Rorer, Paris) i.v. and was maintained by halothane in oxygen. Two $10 \mathrm{ml}$ blood samples were taken from each heifer before anaesthesia. After clotting, the serum samples were pooled. The reproductive tract was exposed at laparotomy and the ovary bearing the dominant follicle was identified. A $5 \mathrm{ml}$ sample of ovarian venous blood draining this ovary was obtained and stored separately. After the results of the aromatase test (see below), healthy dominant follicles were identified. Ovarian serum draining these follicles was pooled. At laparotomy, the ovary bearing the dominant follicle was removed and transferred immediately to the laboratory. After dissection and measurement, follicular fluid was aspirated and stored separately while the walls of the follicles (that is, the theca interna and granulosa) were used in Expt 1. Follicles with aromatase concentrations exceeding those of assay blanks were considered healthy and dominant and their fluid was pooled (pool 1).

Ovaries from cyclic heifers and cows $(n=54)$, as evidenced by the presence of active or regressing corpora lutea, were collected at a local abattoir and transferred within $1 \mathrm{~h}$ to the laboratory. Fluid from all follicles $7-9 \mathrm{~mm}$ in diameter was aspirated and pooled (non-dominant follicles pool) without consideration of follicle size and atresia. All large follicles $(>10 \mathrm{~mm})$ were carefully dissected and measured. Follicular fluid was then aspirated from each follicle and stored separately at $-20^{\circ} \mathrm{C}$. Each follicular wall was dissected into two parts which were transferred to 24well culture plates containing $1 \mathrm{ml}$ minimum essential medium (MEM; Sigma, St Quentin Fallavier) supplemented with $35 \mathrm{ng}$ of $1 \beta 2 \beta\left[{ }^{3} \mathrm{H}\right]$ testosterone (NEN, Les Ulis) and incubated for $3 \mathrm{~h}$. After incubation, the follicular wall fragments were weighed and the amount of ${ }^{3} \mathrm{H}_{2} \mathrm{O}$ in the culture medium was determined (see below). Healthy follicles were identified as having an aromatase activity greater than that of the assay blanks. Fluid from all large healthy follicles was then pooled (pool 2).

\section{Steroid assays}

Oestradiol, testosterone and progesterone concentrations in pools 1 and 2 and in individual follicular fluid samples were quantified using single assays with radioimmunoassays as described by Terqui (1978), Hochereau-de Reviers et al. (1990) and Saumande (1990). The intra-assay coefficients of variation (CV) were $7.7,11.5$ and $11.0 \%$ for oestradiol, testosterone and progesterone, respectively. The minimum detectable values for oestradiol, testosterone and progesterone were $20 \mathrm{pg} \mathrm{ml}^{-1}, 0.2 \mathrm{ng} \mathrm{ml}^{-1}$ and $0.1 \mathrm{ng} \mathrm{ml}^{-1}$, respectively. Charcoal treatment of pool 2 was conducted according to Tsonis et al. (1983).

\section{Aromatase activity}

Aromatase activity of follicular wall fragments was the marker used to assess treatment effects because it is a key enzyme in follicle function. It increases as the follicle matures towards ovulation and decreases when the follicle undergoes atresia (McNatty et al., 1984). The aromatase test was modified from that described and validated for a $3 \mathrm{~h}$ culture by Thatcher et al. (1991). Since the fluids to be tested were available in limited amounts, the experimental design was modified as follows: (i) the culture period was increased to $24 \mathrm{~h}$ because changes in steroidogenesis induced by treatment were unlikely to be observed in fewer than several hours (Westhof et al. (1989); (ii) different treatments were tested on fragments of wall from the same follicle to maximize the potency of the statistical tests to detect treatment effects; and (iii) each treatment was tested in duplicate.

The modified aromatase test was then validated. Large follicles $(n=12)$ were obtained from ovaries from an abattoir. The follicular fluid was aspirated and each follicle was cut into eight fragments. Two fragments were used to determine changes in aromatase activity over time. Each fragment was placed in $1.5 \mathrm{ml}$ of MEM containing $35 \mathrm{ng}\left[{ }^{3} \mathrm{H}\right]$ testosterone. After $2 \mathrm{~h}$, the medium was aspirated and replaced with new medium containing $35 \mathrm{ng}\left[{ }^{3} \mathrm{H}\right]$ testosterone. This was repeated at 4 and $6 \mathrm{~h}$. After the final collection of medium at $8 \mathrm{~h}$ of culture, all follicular wall fragments were placed in unlabelled MEM until $22 \mathrm{~h}$ of culture. At this time, MEM containing $\left.35 \mathrm{ng} \mathrm{[}{ }^{3} \mathrm{H}\right]$ testosterone was added for $2 \mathrm{~h}$. The culture was terminated at $24 \mathrm{~h}$. The amount of ${ }^{3} \mathrm{H}_{2} \mathrm{O}$ present during each time period was measured for each fragment of 
Eight fragments

Follicle at a known stage of maturation

\section{Initiation of culture \\ Addition of

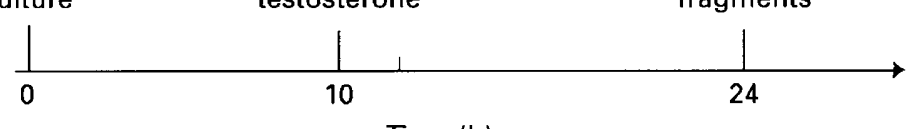 \\ Collection of medium \\ Weight of follicle \\ fragments \\ Time (h)}

(duplicate samples per treatment)

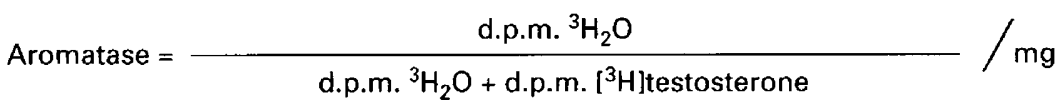

Fig. 1. Experimental design used to assess the in vitro effects of bovine follicular fluid on aromatase activity of the follicular wall.

wall (see below). Three fragments differing in weight were used to determine the relationship between the weights of follicular wall fragments and the amount of ${ }^{3} \mathrm{H}_{2} \mathrm{O}$ produced. Follicular wall fragments of different sizes were generated and incubated from 10 to $24 \mathrm{~h}$ of culture with $35 \mathrm{ng}$ $\left[{ }^{3} \mathrm{H}\right]$ testosterone. At the end of culture, the weights of the wall fragments were assessed and the amount of ${ }^{3} \mathrm{H}_{2} \mathrm{O}$ produced per wall was measured. Three fragments were used to establish the relationship between the amount of label and the amounts of ${ }^{3} \mathrm{H}_{2} \mathrm{O}$ produced per milligram of follicular wall. Follicular wall fragments were incubated with graded amounts of $\left[{ }^{3} \mathrm{H}\right]$ testosterone $(17,35$ and $70 \mathrm{ng}$ per wall) and the amount of ${ }^{3} \mathrm{H}_{2} \mathrm{O}$ produced was measured.

After these initial investigations, the protocol used in the experiments was established (Fig. 1). Samples were cultured for $24 \mathrm{~h}$ in 12-well plates (Corning, Polylabo, Strasbourg) containing $1.5 \mathrm{ml}$ MEM (Sigma, St Quentin Fallavier) with specific amounts of the biological materials to be tested and maintained at $38^{\circ} \mathrm{C}$ in an incubator with $95 \% \mathrm{O}_{2}$. The follicular wall fragments (usually eight per follicle) were placed in culture wells (one wall per well) and test substances were immediately added. After $10 \mathrm{~h}, 35 \mathrm{ng} 1 \beta 2 \beta\left[{ }^{3} \mathrm{H}\right]$ testosterone was added to each well and the culture was continued for $14 \mathrm{~h}$. Testosterone had $75 \%$ of the radioactivity at the $\mathrm{C} 1 \beta$ and $C 2 \beta$ positions and $25 \%$ at the $C 1 \alpha$ and $C 2 \alpha$ positions, and displayed a specific activity of $54 \mathrm{Ci} \mathrm{mmol}^{-1}$. At the end of the culture period, the medium was collected and the weight of each follicular wall measured. Samples of medium $(0.5 \mathrm{ml})$ were then eluted sequentially with $3 \mathrm{ml}$ water and $3 \mathrm{ml}$ methanol on C18 Sep Pak cartridges (Waters, Milford) to separate the tritiated water from the steroids. Aromatase activity was assessed by measuring the transfer of ${ }^{3} \mathrm{H}$ from $1 \beta 2 \beta\left[{ }^{3} \mathrm{H}\right]$ testosterone to ${ }^{3} \mathrm{H}_{2} \mathrm{O}$ (Gore Langton and Dorrington 1981; Thatcher et al., 1991). Aromatase index was expressed as:

$\frac{\text { d.p.m. }{ }^{3} \mathrm{H}_{2} \mathrm{O}}{\text { d.p.m. }{ }^{3} \mathrm{H}_{2} \mathrm{O}+\text { d.p.m. }\left[{ }^{3} \mathrm{H}\right] \text { testosterone }}$ per mg of tissue

Blanks were included in all experiments and the radioactivity in the aqueous eluant of the blanks was subtracted from that observed in the experimental samples.

\section{Effects of biological materials}

Protein concentrations in all biological samples were measured (Bradford, 1976) to ensure that similar amounts of protein were used in the different treatments of each experiment.

Expt 1: dose-response effect of fluid from dominant follicles. This experiment used large follicles $(n=10)$ from 3-4-yearold heifers obtained at hemiovariectomy $48 \mathrm{~h}$ after induction of luteolysis. Each follicle was dissected into eight fragments. The fragments were treated with known amounts of proteins originating from jugular serum ( $175 \mu \mathrm{l}$, fragments 1 and 2$)$ or from fluid from dominant follicles $(90 \mu \mathrm{l}$, fragment 3 and 4; $180 \mu \mathrm{l}$, fragment 5 and 6;360 $\mu \mathrm{l}$, fragment 7 and 8). Follicular fluid from pool 2 was used. The experimental design for this and all following experiments was as described earlier (Fig. 1).

Expt 2: investigation of inhibitory activity in fluid from dominant and non-dominant follicles. This experiment used ovaries from ten cows killed $48 \mathrm{~h}$ after induction of luteolysis. Each large follicle was dissected and cut into eight fragments. The test substances used were jugular serum (175 $\mu$ l, fragments 1 and 2), fluid from dominant follicles $(175 \mu$ l from pool 1 , fragments 3 and 4$)$, ovarian venous serum draining ovaries with dominant follicles (185 $\mu$ l, fragments 5 and 6), and fluid from non-dominant follicles (175 $\mu \mathrm{l}$, fragments 7 and 8 ).

Expt 3: relationship between inhibitory activity of fluid from dominant follicles and steroid content. Fourteen ovaries bearing a large $(>10 \mathrm{~mm})$ follicle were obtained from cyclic animals at a local abattoir. The follicles were dissected and cut into eight fragments. The test substances used were jugular serum (175 $\mu \mathrm{l}$, fragments 1 and 2), fluid from dominant follicles (175 $\mu \mathrm{l}$ from pool 2, fragments 3 and 4), charcoaltreated fluid from dominant follicles $(195 \mu \mathrm{l}$, fragments 5 and 6), and serum $(175 \mu \mathrm{l})$ supplemented with $2 \mathrm{ng}$ ovine FSH $\mathrm{ml}^{-1}$ (fragments 7 and 8). The FSH had crossreactions with thyroid-stimulating hormone (TSH) and LH that did not exceed 0.1 and $0.5 \%$, respectively. The concentration used (2 $\mathrm{ng} \mathrm{ml}^{-1}$ ) was selected according to Saumande (1990). 
Expt 4: effects of follicular fluid in the presence of FSH. Fifteen ovaries bearing a large $(>10 \mathrm{~mm}$ ) follicle were obtained from cyclic animals at a local abattoir. The follicles were dissected and cut into eight fragments. The test substances used were jugular serum (90 $\mu \mathrm{l}$, fragments 1 and 2), jugular serum (175 $\mu$ l, fragments 3 and 4 ), fluid from dominant follicles ( $90 \mu \mathrm{l}$ from pool 1, fragments 5 and 6), fluid from dominant follicles (180 $\mu$, fragments 7 and 8). In addition, 2 ng FSH $\mathrm{ml}^{-1}$ was added to all culture wells.

Expt 5: effect of ovarian venous serum draining a dominant follicle on aromatase activity. Twelve ovaries were obtained from cyclic animals at a local abattoir. Large $(\geq 10 \mathrm{~mm})$ follicles were dissected and cut into eight fragments. The test substances used were ovarian venous serum draining a dominant follicle $(90 \mu \mathrm{l}$, fragments 1 and 2; $180 \mu \mathrm{l}$, fragments 3 and $4 ; 360 \mu \mathrm{l}$, fragments 5 and 6), and serum (360 $\mu \mathrm{l}$, fragments 7 and 8 ).

\section{Electrophoresis}

The in vitro experiments suggested that inhibition of aromatase after culture with fluid from dominant follicles was due to a protein or peptide. Therefore, two-dimensional PAGE was used to identify the protein. The rationale for this approach was that comparison of the two-dimensional pattern of proteins in fluid from dominant follicles, which was inhibitory in the aromatase test, with fluid from nondominant follicles and incubation medium, which were both inactive in the aromatase test, would permit the identification of compounds involved in the inhibition of aromatase.

Large dominant follicles $(n=4)$ and medium sized nondominant follicles $(n=3)$ were obtained from four heifers killed $48 \mathrm{~h}$ after luteolysis to obtain samples of proteins synthesized de novo. All follicles were dissected and cultured intact in $4 \mathrm{ml}$ methionine-free MEM (Sigma, St Quentin Fallavier) supplemented with $100 \mu \mathrm{Ci}$ of [ $\left.{ }^{35} \mathrm{~S}\right]$ methionine (NEN, Les Ulis) for $24 \mathrm{~h}$ at $38^{\circ} \mathrm{C}$ with $95 \% \mathrm{O}_{2}$. At the end of culture, the culture medium was pooled. Labelled follicular fluid was also aspirated and pooled. Both samples were extensively dialysed against deionized water using dialysis tubing with a molecular mass exclusion limit of $6-8 \mathrm{kDa}$. Radioactivity in the retentate was determined by scintillation spectrometry.

Two-dimensional electrophoresis was performed on equal numbers of counts (200 000 d.p.m.), according to Roberts et al. (1984). Samples were dissolved in $1 \mathrm{~mol}$ urea $\mathrm{l}^{-1}, 2 \%(\mathrm{v} / \mathrm{v})$ $\mathrm{NP} 4 \mathrm{O}$ and $0.5 \%(\mathrm{w} / \mathrm{v})$ dithiothreitol. Proteins were resolved in the first dimension by isoelectric focusing in $4 \%(\mathrm{w} / \mathrm{v})$ polyacrylamide tube gels containing $250 \mathrm{mmol} N-N^{\prime}-$ diallyltartramide (DATD), 8.0 mol urea $\mathrm{l}^{-1}, 2 \%$ (v/v) NP4O and $5.1 \%(\mathrm{v} / \mathrm{v})$ ampholytes $(\mathrm{pH} 3-10)$. Tube gels were equilibrated in 50 mmol Tris- $\mathrm{HCl} \mathrm{l}^{-1}, \mathrm{pH} \mathrm{6.8,} \mathrm{containing} \mathrm{1 \%}$ $(\mathrm{w} / \mathrm{v})$ SDS and $1 \%(\mathrm{v} / \mathrm{v}) \beta$-mercaptoethanol, and were subjected to electrophoresis in the second dimension on $10 \%$ $(\mathrm{w} / \mathrm{v})$ polyacrylamide gels in the presence of $0.5 \%(\mathrm{w} / \mathrm{v})$ SDS.

Slab gels were stained with Coomassie blue R250, destained in acetic acid, ethanol and water, soaked in water, equilibrated with $1 \mathrm{~mol}$ sodium salicylate $\mathrm{l}^{-1}(30 \mathrm{~min})$, and dried. Fluorographs were prepared with Kodak XAR X-ray film, and exposed for 22 days at $-70^{\circ} \mathrm{C}$. The gels were scanned to quantify the concentration of proteins in the spots of interest. The percentage of the total label of a gel contained in specific spots was determined using the Kepler software (Driancourt et al., 1996a) and values among samples were compared.

\section{Immunohistochemistry to detect hsp 90 in ovarian follicles}

Bovine ovaries were obtained from a local abattoir, fixed for 4 days in $4 \%(\mathrm{w} / \mathrm{v})$ paraformaldehyde and embedded in paraffin wax. Sections $(8 \mu \mathrm{m})$ were cut from three ovaries and processed for immunostaining according to the method of Meduri et al. (1996) and using the universal LSAB kit (Dako, Trappes). Paraffin wax was removed from randomly

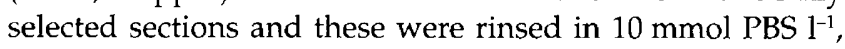
$\mathrm{pH}$ 7.4. The sections were incubated at room temperature for $20 \mathrm{~min}$ with normal swine serum diluted 1:10 in PBS containing $5 \%(\mathrm{w} / \mathrm{v})$ BSA to block non-specific background staining. The sections were then incubated overnight at $4^{\circ} \mathrm{C}$ in a moist chamber with equal amounts of commercially available rabbit polyclonal anti-hsp 84 and anti-hsp 86 antibodies (Affinity Bioreagents, Golden, CO) at $10 \mu \mathrm{g} \mathrm{ml}^{-1}$. Negative control sections were incubated with $10 \mu \mathrm{g}$ normal rabbit IgG ml-1 (Sigma, St Quentin Fallavier). After rinsing three times for $3 \mathrm{~min}$, sections were treated with biotinylated swine anti-rabbit IgG for $15 \mathrm{~min}$. Endogenous peroxidase was then inhibited by a $10 \mathrm{~min}$ incubation in PBS containing $3 \%(\mathrm{v} / \mathrm{v}) \mathrm{H}_{2} \mathrm{O}_{2}$. Finally, the sections were treated with streptavidine-peroxidase conjugate for $15 \mathrm{~min}$ at room temperature. The chromogen used was 3,3-diaminobenzidine. After counterstaining with $0.5 \%(\mathrm{w} / \mathrm{v})$ methyl green, the sections were examined by light microscopy.

\section{One-and two-dimensional western blotting to detect hsp 90 in ovarian follicles and follicular fluid}

Large follicles $(n=26)$ were obtained after dissection of ovaries obtained from a local abattoir. Follicular fluid was aspirated and a small aliquot was used to estimate oestradiol, testosterone and progesterone concentrations in follicular fluid. The ratio between oestradiol and progesterone concentrations was used to identify healthy follicles (oestradiol:progesterone $>1$ ) and atretic follicles (oestradiol:progesterone $<1$ ). The follicular wall (granulosa and theca interna cells) was immediately transferred to ice-

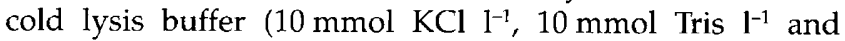
0.5 mmol EDTA $\left.~^{-1}\right)$ containing protease inhibitors $(1 \mu \mathrm{mol}$ phenyl methyl sulfonyl fluoride $\mathrm{I}^{-1}, 100 \mu \mathrm{mol} N$-tosyl-Lphenylalanine chloromethyl ketone $\mathrm{l}^{-1}$ and $100 \mu \mathrm{mol} N-\alpha-p$ tosyl-L-lysine chloromethyl ketone $\mathrm{l}^{-1}$ ). Each sample was sonicated briefly, centrifuged at $8700 \mathrm{~g}$ for $30 \mathrm{~s}$ and the concentration of proteins in the supernatant was quantified according to Bradford (1976). Equal amounts of cellular or follicular fluid proteins were then fractionated by SDS-PAGE under reducing conditions. Proteins were electrotransferred 
onto a nitrocellulose filter $(0.2 \mu \mathrm{m}$ pore size) overnight at $4^{\circ} \mathrm{C}$. After electrotransfer, filters were incubated for $2 \mathrm{~h}$ at room temperature with $20 \mathrm{mmol}$ Tris-buffered saline (TBS) $1^{-1}, \mathrm{pH} 7.6$, containing $10 \%(\mathrm{w} / \mathrm{v})$ non-fat dry milk powder (NFDMP) and $0.2 \%(\mathrm{w} / \mathrm{v})$ Tween 20 to saturate non-specific binding sites. The filters were then incubated for $1 \mathrm{~h}$ at $37^{\circ} \mathrm{C}$ with either rabbit antiserum raised against the $\mathrm{C}$-terminal dodecapeptide of human hsp $90 \beta$ (AB119) (Lees Miller and Anderson, 1989) or a commercially available rabbit polyclonal anti-hsp 84 antibody (Affinity Bioreagents, Golden, CO). Both antibodies were diluted 1:750 in TBS containing $5 \%(w / v)$ NFDMP and $0.2 \%(\mathrm{w} / \mathrm{v})$ Tween 20 . The filters were washed twice in TBS containing $10 \%(\mathrm{w} / \mathrm{v})$ NFDMP and $0.2 \%(\mathrm{w} / \mathrm{v})$ Tween 20 and then incubated for $1 \mathrm{~h}$ at $37^{\circ} \mathrm{C}$ in TBS containing $5 \%(\mathrm{w} / \mathrm{v})$ NFDMP, $0.05 \%(\mathrm{w} / \mathrm{v})$ Tween 20 and peroxidaselabelled goat anti-rabbit IgG (final dilution 1:1000). The filters were again rinsed twice in TBS containing 10\% (w/v) NFDMP and $0.2 \%(w / v)$ Tween 20 . The signal was revealed by chemiluminescence (Amersham, Les Ulis).

In addition, purified chicken hsp 90 was included in one of the gels to identify the signal present in the other samples as hsp 90. Follicular fluid $(5 \mu \mathrm{l})$ was loaded onto tube gels prepared as described for the electrophoresis and the blotting procedure was conducted as described earlier to achieve a two-dimensional western blot. The antibody used was AB119.

\section{Effect of hsp 90 on aromatase activity}

Two experiments were conducted to determine whether hsp 90 affects the concentration or activity $\left(K_{\mathrm{m}}\right.$ and $V_{\max }$ values) of aromatase in granulosa cells. In the first experiment, four follicles were each cut into two. The wall fragments were cultured in $600 \mu \mathrm{l}$ MEM for $24 \mathrm{~h}$ with or without $150 \mu \mathrm{g}$ pure hsp 90. After $24 \mathrm{~h}$, the follicular wall fragments were lysed in lysis buffer, sonicated and their protein content was determined according to Bradford (1976). Equal amounts of proteins from the control and hsp-treated follicular wall fragments were fractionated using SDS-PAGE under reducing conditions. Proteins were electrotransferred as described earlier and the blots were probed with a 1:500 dilution of an antibody against equine aromatase.

In the second experiment, four follicles were used to estimate $K_{m}$ and $V_{\max }$ values of aromatase in the presence and absence of purified hsp 90. Each follicle was split into six follicular wall fragments. Three of the samples were incubated in the presence of graded amounts of $\left[{ }^{3} \mathrm{H}\right]$ testosterone $\left(5 \times 10^{-7}, 1 \times 10^{-6}\right.$ and $\left.2 \times 10^{-6} \mathrm{~mol} \mathrm{l}^{-1}\right)$ in $1.2 \mathrm{ml}$ MEM. The three other samples were similarly incubated (one fragment per concentration), but in the presence of $150 \mu \mathrm{g}$ of pure hsp 90 . At 3, 6 and $9 \mathrm{~h}$ of culture, $150 \mu \mathrm{l}$ of medium was aspirated. $K_{\mathrm{m}}$ and $V_{\max }$ values were calculated according to Michaelis (1922).

\section{Statistical analysis}

Correlational analysis was used for the validation steps of the aromatase assay. Treatment effects were detected after transformation (arcsin $\vee v$ ) by ANOVA. The sources of variation were follicle, treatment, and follicle $\times$ treatment interaction. The error term for testing treatment effects was the mean square for the follicle $\times$ treatment interaction. Results are means \pm SEM.

\section{Results}

\section{Features of the biological materials}

Nine of ten dominant follicles collected for pool 1 and 20 of 54 follicles collected for pool 2 were healthy, as evidenced by aromatase activity greater than the background value. The mean diameter of follicles in pools 1 and 2 were $12.4 \pm 0.2$ and $10.8 \pm 0.1 \mathrm{~mm}$, respectively. Steroid concentrations of pools 1 and 2 were 240 and $77.6 \mathrm{ng} \mathrm{ml}^{-1}$ for oestradiol and 13 and $18.4 \mathrm{ng} \mathrm{ml}^{-1}$ for testosterone, respectively. Fluid from non-dominant follicles contained 3 and $40 \mathrm{ng} \mathrm{ml}^{-1}$ oestradiol and testosterone, respectively, while ovarian venous serum contained 0.6 and $2 \mathrm{ng} \mathrm{ml}^{-1}$ of these steroids. Charcoal treatment removed 86 and $92 \%$ of oestradiol and testosterone, respectively.

\section{Validation of aromatase test}

Aromatase concentrations of six of the 12 follicles were in the range of background concentrations and these were removed from the study.

No significant time effect was found from the plot of aromatase activity against time, suggesting that aromatase activity did not markedly change during the $24 \mathrm{~h}$ culture. When expressed as a percentage of the initial incubation period, aromatase activity at 2-4, 4-6, 6-8 and 22-24 h was $89,105,119$ and $78 \%$, respectively. There was a highly significant relationship $(r=0.93, P<0.01)$ between weight of follicular wall fragments and amount of substrate metabolized to ${ }^{3} \mathrm{H}_{2} \mathrm{O}$ (Fig. 2a). In addition, there was a highly significant correlation $(r=0.62, P<0.01)$ between the amount of substrate and the amount of ${ }^{3} \mathrm{H}_{2} \mathrm{O}$ generated per milligram of follicular wall (Fig. 2b).

\section{Effects of follicular fluid and venous serum on aromatase}

Expt 1: dose-response effect of follicular fluid. A significant $(P<0.05)$ treatment effect was observed in the comparison of aromatase activity in the presence of follicular fluid or serum (Table 1). In the presence of high concentrations of fluid from dominant follicles $(360 \mu \mathrm{l})$, aromatase activity was significantly $(P<0.02)$ reduced compared with that in the serum-treated follicular wall. Lower amounts of follicular fluid had a lower inhibitory effect $(P<0.1)$ compared with serum.

Expt 2: investigation of inhibitory activity in fluid from dominant and non-dominant follicles. A highly significant treatment effect $(P<0.01)$ was detected in this experiment. There was marked inhibition of aromatase activity in the 

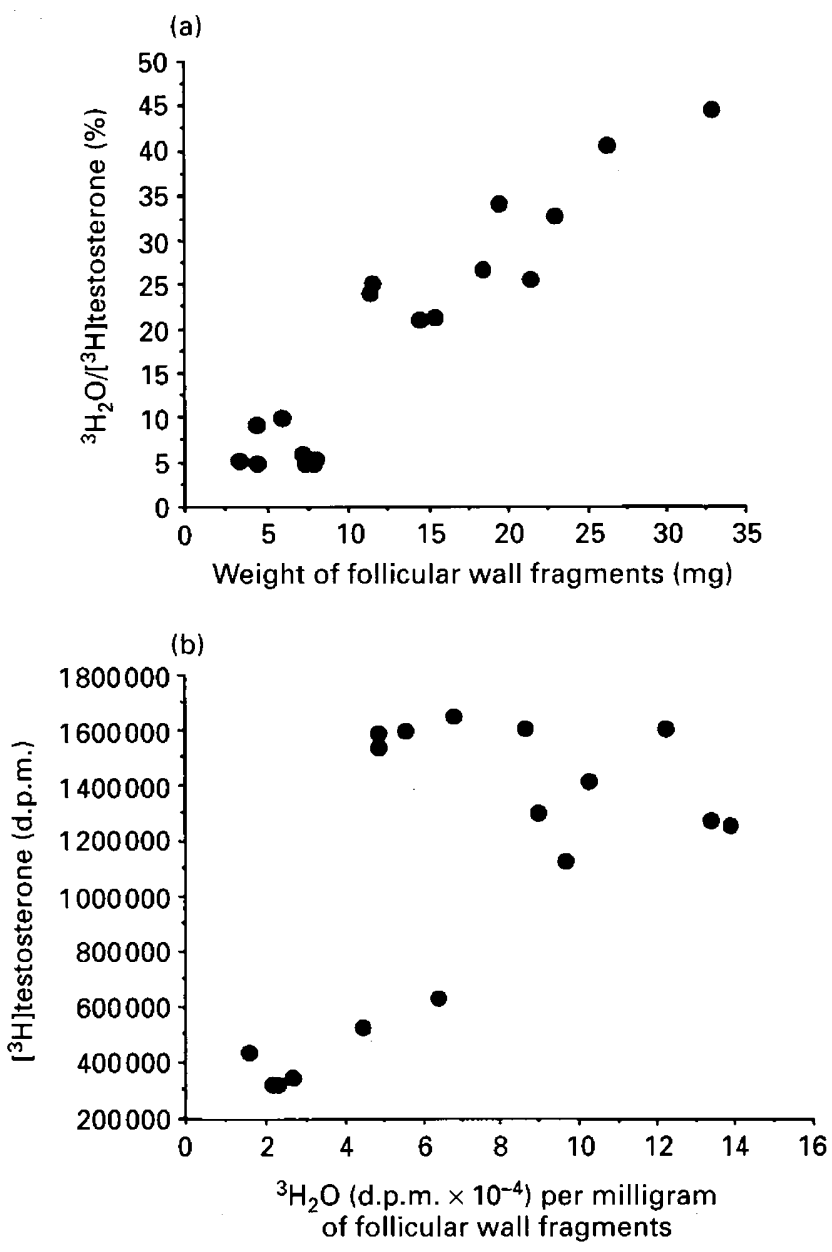

Fig. 2. Effects of (a) weight of follicular wall sample and (b) amount of $\left[{ }^{3} \mathrm{H}\right]$ testosterone on aromatase activity in bovine follicles $(n=18$ follicular wall fragments).

presence of fluid from dominant follicles $(P<0.01$ versus other treatments), whereas none of the other treatments (fluid from non-dominant follicles and ovarian venous serum draining the dominant follicle) had detectable activities (Table 1).

Expt 3: relationship between inhibitory activity of fluid from dominant follicles and steroid content. Nine of the 14 follicles in this experiment were healthy, as evidenced by aromatase activity greater than that of the blank samples. A significant

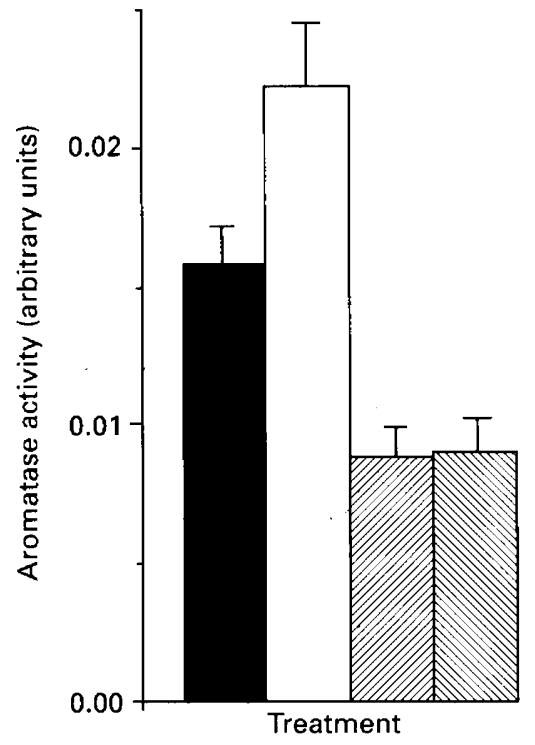

Fig. 3. Effects of proteins (12\%) from ( $\square$ ) serum, ( $\square$ ) serum in the presence of $2 \mathrm{ng} \mathrm{FSH} \mathrm{ml}^{-1}$, (包) fluid from dominant follicles (pool 2) and $(\mathbb{8})$ charcoal-treated fluid from dominant follicles (pool 2) on aromatase activity in bovine follicles $(n=9$ follicular wall fragments). Values are means for the duplicate samples.

treatment effect $(P<0.01)$ was observed from comparison of the effects of similar amounts of proteins from serum, fluid from dominant follicles and charcoal-treated fluid from dominant follicles. This treatment effect was due to the strong inhibition of aromatase in the presence of fluid from dominant follicles (Fig. 3) $(P<0.01$ compared with serum). Aromatase activity in the presence of charcoal-treated fluid from dominant follicles was similar to that observed in the presence of untreated follicular fluid (Fig. 3). Aromatase activity in the presence of $2 \mathrm{ng} \mathrm{FSH} \mathrm{ml}^{-1}$ was significantly increased (Table 1) $(146 \%$ of the basal activity) compared with basal conditions $(P<0.05)$.

Expt 4: effects of follicular fluid in the presence of FSH. Eight of the 15 follicles used in this experiment were healthy as evidenced by aromatase activity greater than that of the blank samples. The effects of serum and fluid from dominant follicles in the presence of $2 \mathrm{ng} \mathrm{FSH} \mathrm{ml}{ }^{-1}$ were investigated on these healthy follicles. This concentration was shown to stimulate aromatase activity in Expt 3. A significant treatment

Table 1. The effects of different concentrations of follicular fluid (Expt 1) and fluid from dominant and non-dominant follicles (Expt 2) on the activity of aromatase in bovine follicles

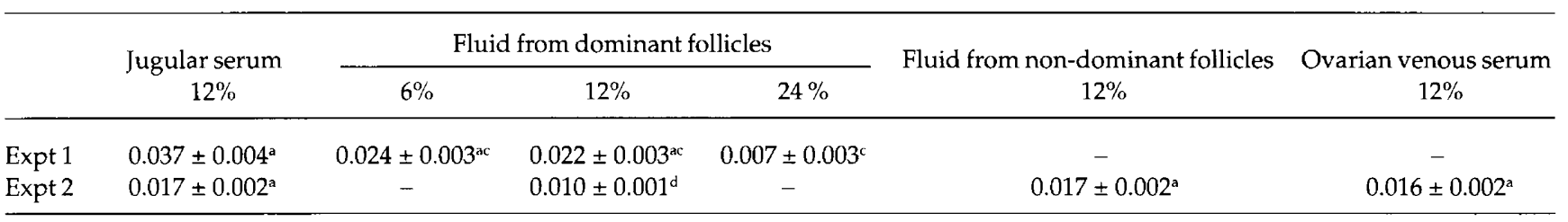

Values are given in arbitrary units.

Within each Expt, different letters indicate significant differences (a versus $b, P<0.05$; a versus $c, P<0.02 ;$ a versus d, $P<0.01$ ). 


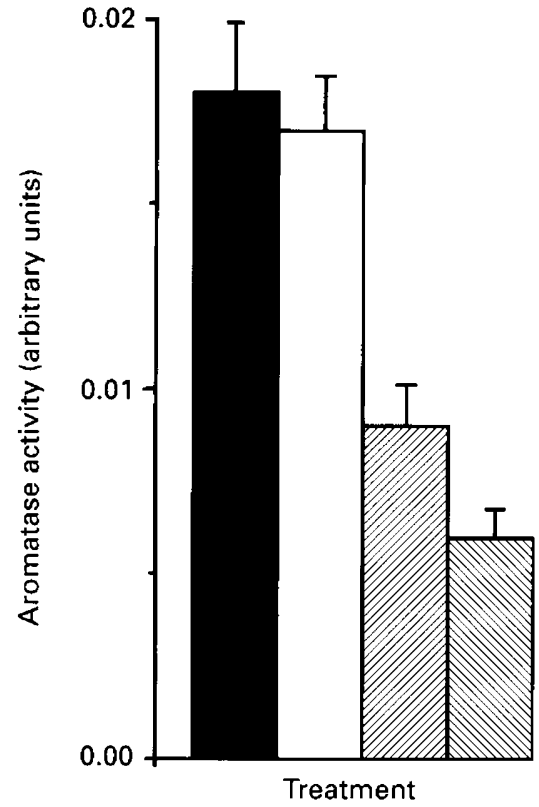

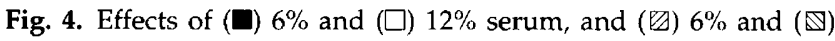
$12 \%$ fluid from dominant follicles on aromatase activity in bovine follicular wall fragments $(n=8)$ cultured in FSH-stimulated $\left(2 \mathrm{ng} \mathrm{ml}^{-1}\right)$ conditions. Values are means for the duplicate samples.

effect $(P<0.01)$ was caused by significant inhibition of aromatase activity in the presence of fluid from dominant follicles at both concentrations (Fig. 4). Inhibition caused by $180 \mu \mathrm{l}$ follicular fluid was marginally $(P<0.1)$ stronger than that observed with $90 \mu \mathrm{l}$ follicular fluid (Fig. 4).

Expt 5: effect of ovarian venous serum draining a dominant follicle on aromatase activity. No significant difference was observed among follicular wall fragments treated with 90 $(0.019 \pm 0.003), 180(0.020 \pm 0.003)$ or $360 \mu l(0.015 \pm 0.003)$ of ovarian venous serum and those treated with $360 \mu$ lof jugular serum $(0.017 \pm 0.003)$. This shows that ovarian venous serum at concentrations up to $24 \%$ has no activity in the aromatase test.

\section{Electrophoresis}

In the two-dimensional gels, 25-70 spots were detected. The major proteins (three slightly acidic proteins at $45 \mathrm{kDa}$ and a group of basic proteins at $30 \mathrm{kDa}$ ) were common to all samples and their concentrations were not related to the origin of the sample (Fig. 5).

In contrast, amongst the proteins present in moderate amounts (darkness intensity $>100000$ arbitrary units), three groups had interesting characteristics. The first was a set of high molecular weight basic proteins that were only found in the incubation medium. The differences in the two other groups were only quantitative. One protein $(90 \mathrm{kDa}$, pI 5.8) was present in greater $(P<0.05)$ amounts in the fluid from dominant follicles $(2.0 \pm 0.09 \%$ of the total proteins) than in the incubation medium ( $1.3 \pm 0.1 \%$ of the total proteins) and the fluid from non-dominant follicles $(0.86 \pm 0.13 \%$ of the total proteins) (Fig. 5). In contrast, one group of pkteinyt (34-35 kDa, pI 5.7) was present in greater amounts $(P<0.05)$ in the incubation medium $(3.1 \pm 0.1 \%$ of the total proteins) than in fluid from dominant $(1.4 \pm 0.1 \%$ of the total proteins) and non-dominant $(1.3 \pm 0.2 \%$ of the total proteins) follicles.

\section{Immunohistochemical evidence that hsp 90 is present in the bovine ovary}

In medium size healthy follicles (1-4 $\mathrm{mm}$ ), a positive hsp 90 signal was identified in a small fraction of granulosa cells (around $10 \%$ ) and in a few thecal cells. In large healthy follicles, the proportion of positive cells in the granulosa layer increased to $30-40 \%$, while the staining in thecal cells remained limited. Interestingly, the cumulus cells contained markedly more label than the rest of the granulosa layer. Atresia of large follicles resulted in a decrease in the proportion of labelled granulosa cells and an absence of labelled thecal cells (Fig. 6).

\section{Evidence that follicles and follicular fluid contain hsp 90}

A signal at $90 \mathrm{kDa}$ was detected in all samples after follicular wall proteins were separated with one-dimensional PAGE, electrotransferred and the membrane probed with the anti-hsp 84 antibody (Fig. 7a). Of the 26 follicles studied, 13 were identified as healthy by an oestradiol:progesterone ratio $>1$. The size of the follicles ranged from 6 to $18 \mathrm{~mm}$. Within this population, there was no relationships between cellular hsp 90 content and progesterone $(r=0.16)$ or testosterone $(r=-0.24)$ concentrations of follicular fluid. In contrast, cellular hsp 90 content and oestradiol concentration of follicular fluid tended to be negatively related $(r=-0.44$, $P=0.12$ ). The relationships between follicle size, follicle atresia and cellular hsp content were analysed in all 26 follicles by two-way ANOVA. There was no effect of atresia, or size $\times$ atresia interaction, but a significant size effect was detected $(P<0.05)$. Cellular hsp contents were $32.8 \pm 5.7$, $28.0 \pm 4.2$ and $9.0 \pm 3.2$ arbitrary units in follicles of $6-8,9-12$ and $\geq 13 \mathrm{~mm}$, respectively.

Follicular fluid proteins from the same samples were probed with the AB119 antibody and provided a major signal at $90 \mathrm{kDa}$ (Fig 7a). The amount of hsp 90 present in the follicular fluid was not related to progesterone or testosterone concentrations ( $r=-0.09$ and 0.08 , respectively). In contrast, the relationship between follicular fluid hsp 90 and aromatase (measured by the oestradiol:testosterone ratio) approached significance $(r=-0.47, P=0.1)$. Sizerelated changes in follicular fluid hsp 90 were examined in healthy and atretic follicles by correlational analysis. In healthy follicles, the regression line linking hsp $(y)$ and follicle size $(x)$ was $y=43.7-1.91 x(r=0.92)$, while in atretic follicles, it was $y=23.6-0.99 x(r=0.78)$ (Fig. 8). Comparison of these lines indicate that follicular fluid hsp content decreases with follicle size and that there is about $50 \%$ more hsp 90 in the fluid of healthy follicles compared with atretic follicles.

Follicular fluid proteins were separated by twodimensional PAGE and the blot was probed with AB119 
(a)

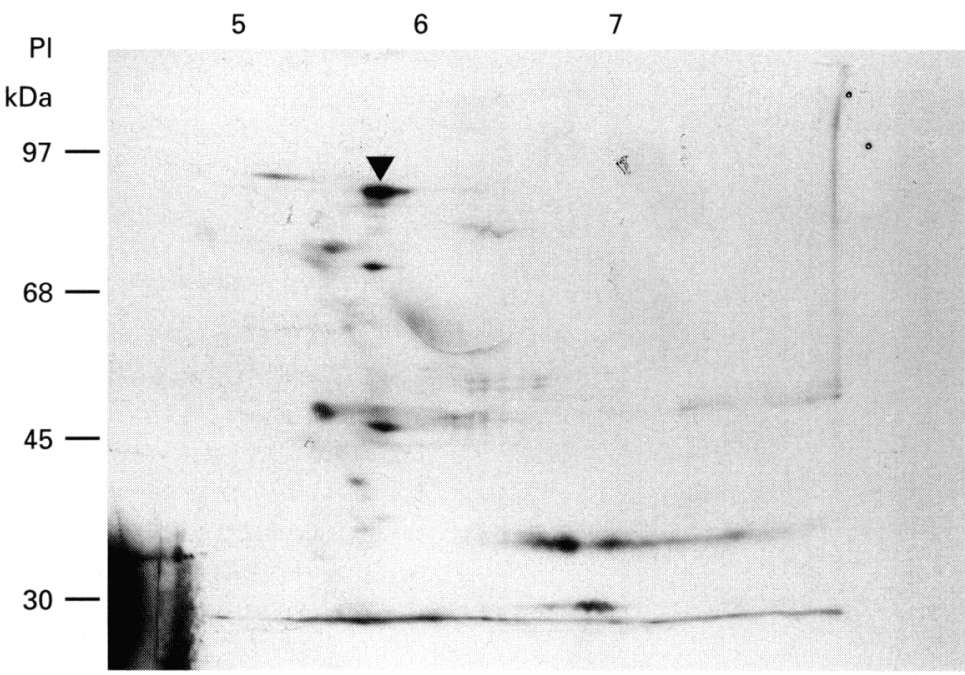

(b)

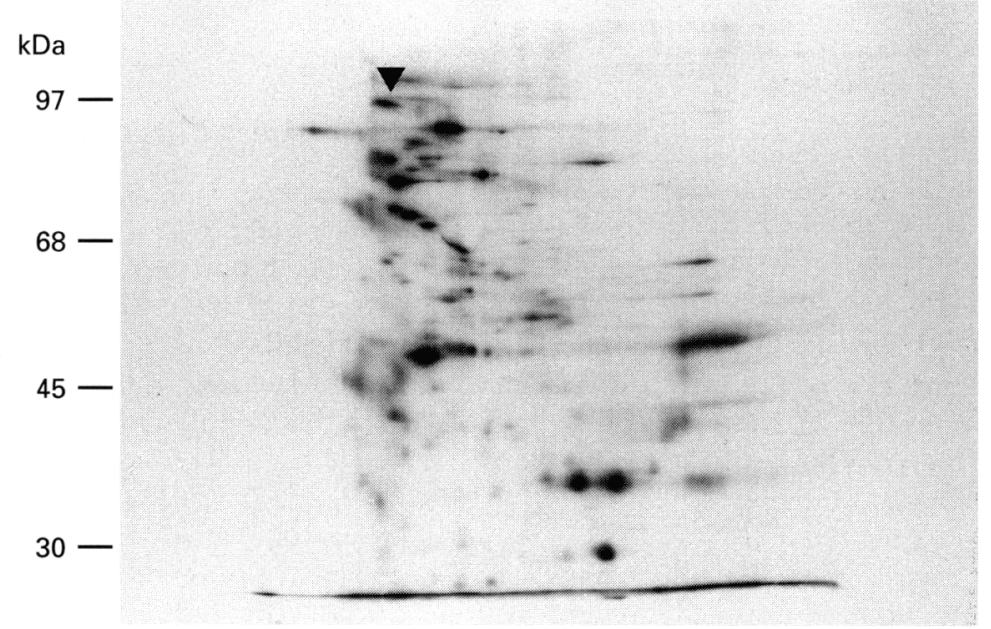

(c)

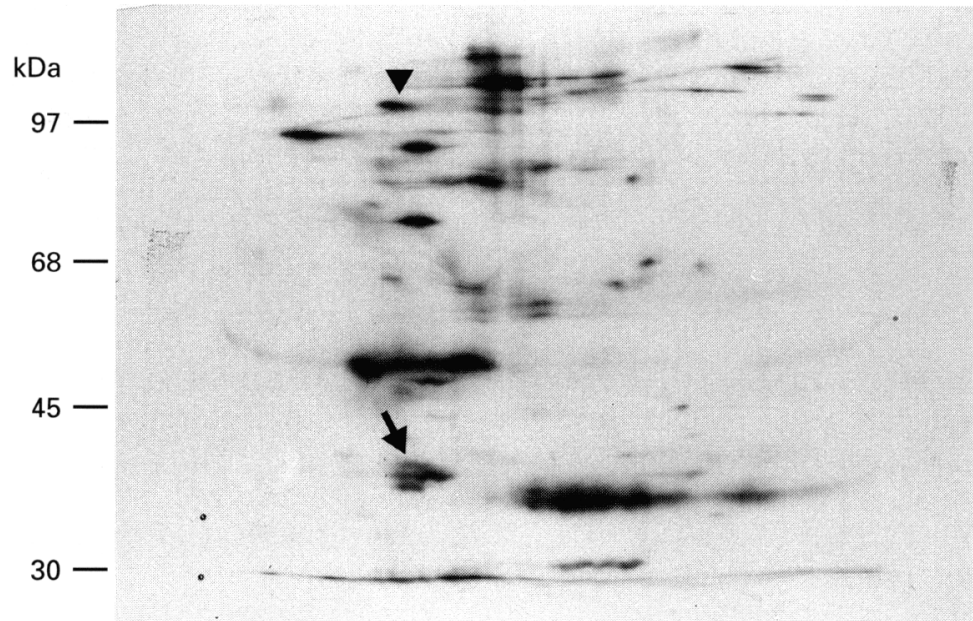

Fig. 5. Two-dimensional pattern of de novo synthesized proteins present in bovine follicles. (a) Fluid from dominant follicles, (b) fluid from non-dominant follicles and (c) culture medium of fluid from dominant follicles. Molecular weight markers are shown on the left. Charge separation produced by isoelectrofocusing is indicated at the top of the gels. The compounds of interest are at 90 (arrowheads) and $34 \mathrm{kDa}$ (arrow). 

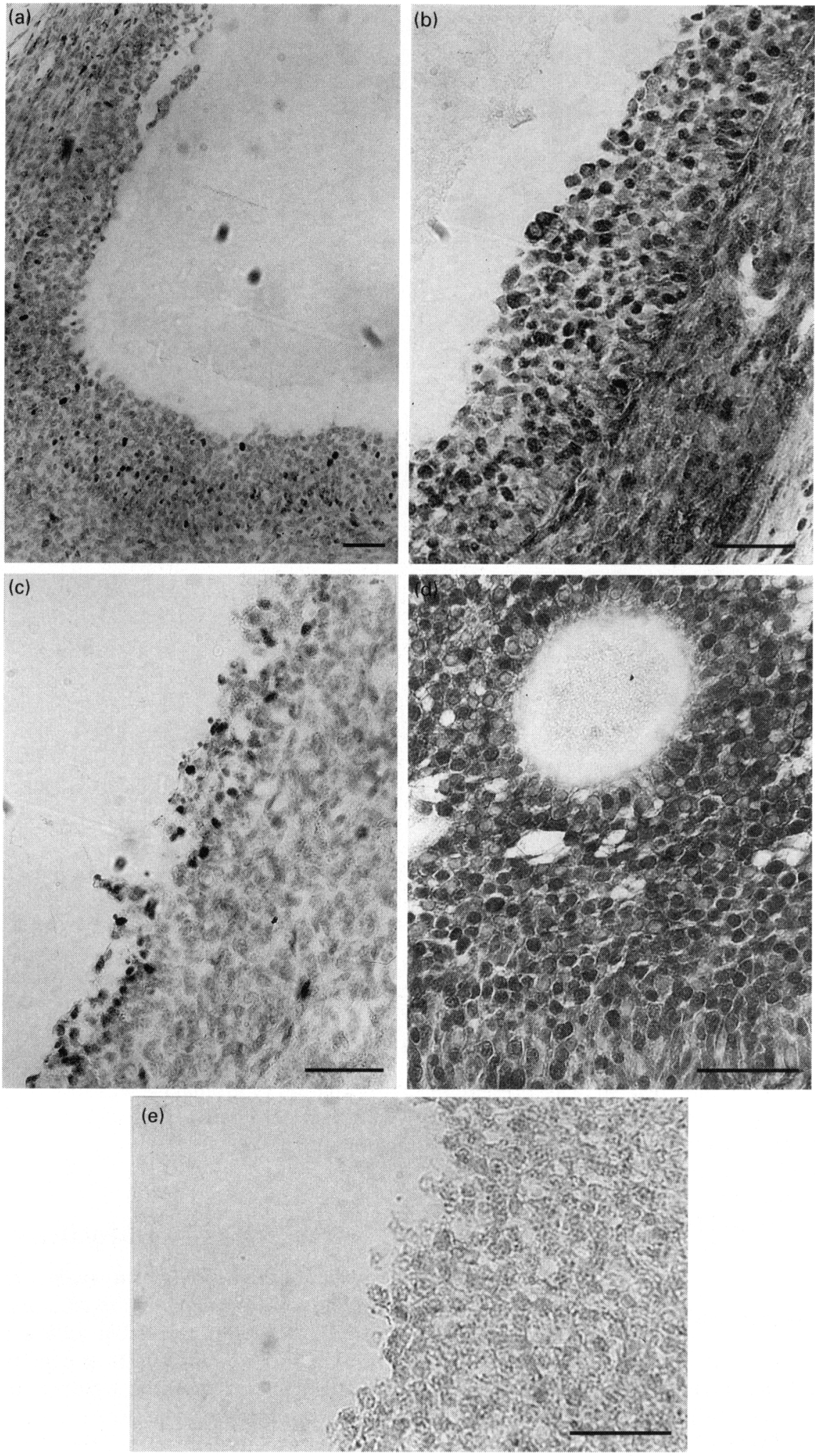

Fig. 6. Immunohistochemical detection of heat shock protein 90 (hsp 90) in bovine follicles. (a) Small healthy follicle, (b) large healthy follicle, (c) large atretic follicle, (d) cumulus cells of a large healthy follicle. Labelled cells appear dark. (e) Follicular wall fragment in which the first antibody has been replaced by a similar concentration of rabbit $\operatorname{IgG}$. Scale bars represent $50 \mu \mathrm{m}$. 
(a)

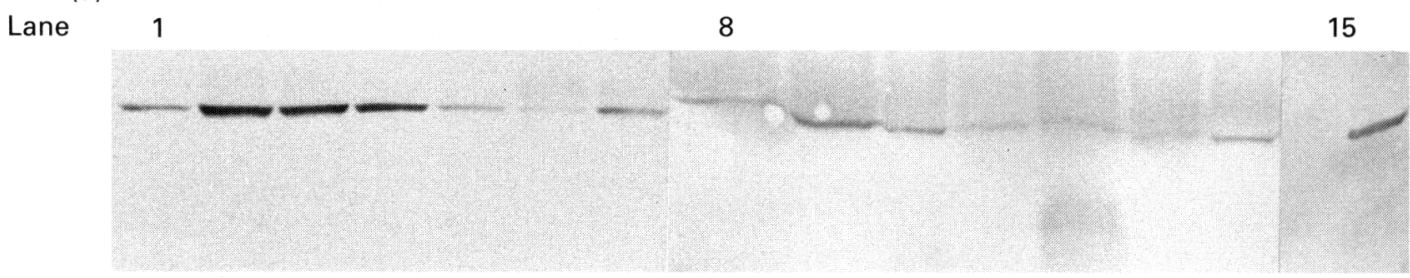

(b)

$\mathrm{PI}$ 5

6

7

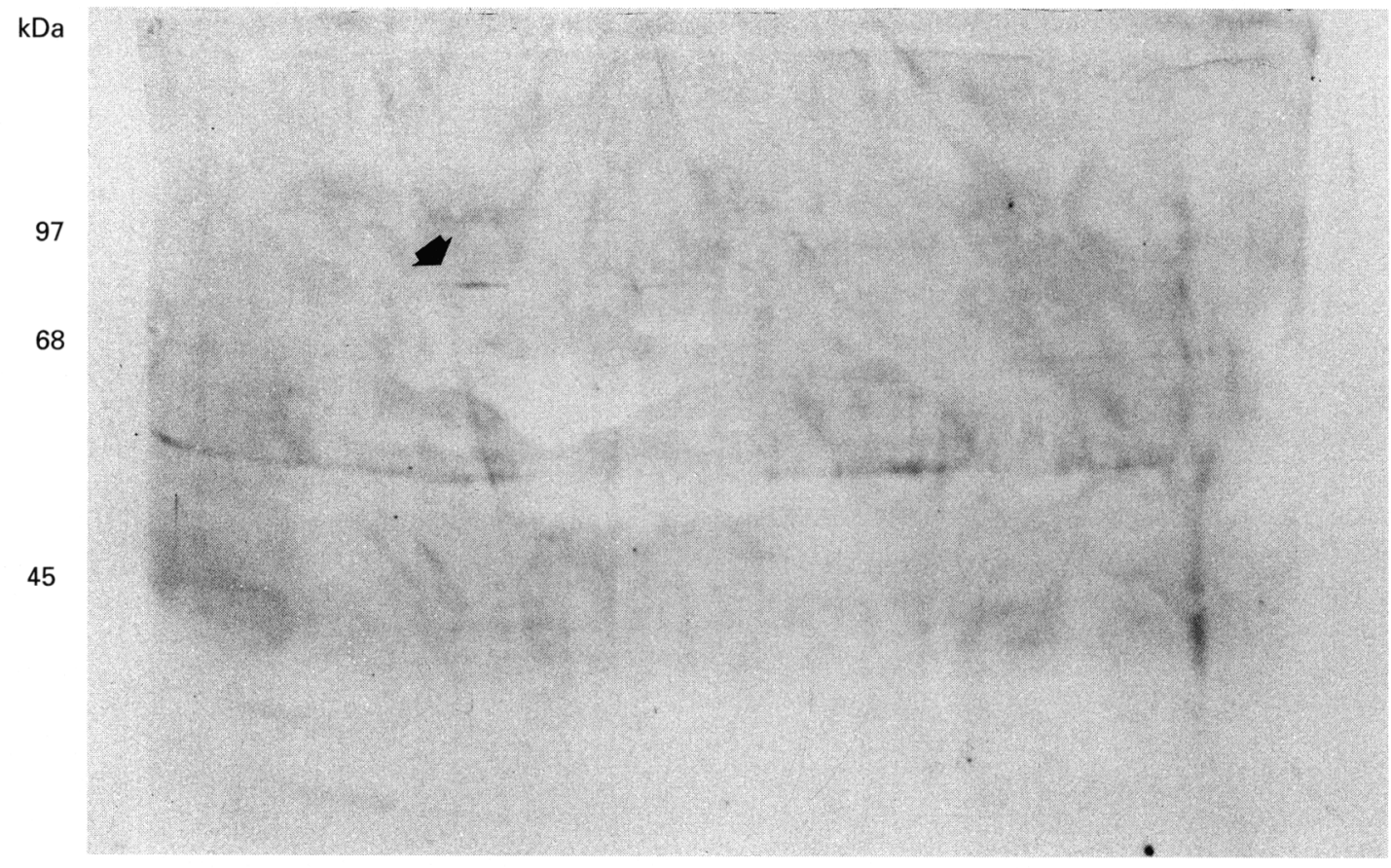

Fig. 7. (a) One- and (b) two-dimensional western blots of bovine follicular fluid. In (a), lanes 1-7 contain follicular wall proteins, lanes 8-14 contain $5 \mu$ l follicular fluid from the same follicles and lane 15 contains purified chicken heat shock protein 90 (hsp 90). In (b), hsp 90 is indicated by an arrow.

antibody. This demonstrated that hsp 90 was present in follicular fluid as a single spot with physiochemical features (90 kDa, pI 5.8) similar to those in the spot identified earlier as preferentially stored in the follicular fluid (Fig. $7 b$ ). The signal was absent when the antibody was incubated overnight at $4^{\circ} \mathrm{C}$ with pure hsp 90 (data not shown).

\section{Evidence that hsp 90 can modulate aromatase activity of follicular wall fragments}

The presence of hsp 90 resulted in limited accumulation of ${ }^{3} \mathrm{H}_{2} \mathrm{O}$ per milligram follicular wall irrespective of the amount of $1 \beta 2 \beta\left[{ }^{3} \mathrm{H}\right]$ testosterone provided in the culture (Fig. 9a). The estimates of $K_{\mathrm{m}}$ and $V_{\max }$ values (Fig. $9 \mathrm{~b}$ ) show that $K_{\mathrm{m}}$ was the main parameter affected by hsp 90 . However, in the three other follicles treated with hsp 90 , both $K_{\mathrm{m}}$ and $V_{\max }$ values were altered in the presence of hsp 90 .

The effect of hsp 90 on the amount of aromatase present in the follicular wall was investigated. In each of two replicates, the amount of aromatase was found to be similar in control and hsp 90-treated follicular wall fragments (data not shown).

\section{Discussion}

The aim of this study was to analyse the effects of follicular fluid on follicle maturation in vitro (measured by aromatase activity), to identify possible follicle regulators within the fluid. In addition, the effects of ovarian venous serum were investigated to determine whether inter-follicle regulation occurred in cattle. The test system used follicular wall fragments to measure aromatase activity, as used previously in mares (Sirois et al., 1989) and sheep (Driancourt et al., 1996b). This model was selected because it does not involve disruption of cell-cell communication or granulosa-theca interactions and allows maintenance of cellular heterogeneity in each of the tissue layers (Lahteennaki et al., 1982; Meduri et al., 1992). It therefore permits the effects of 


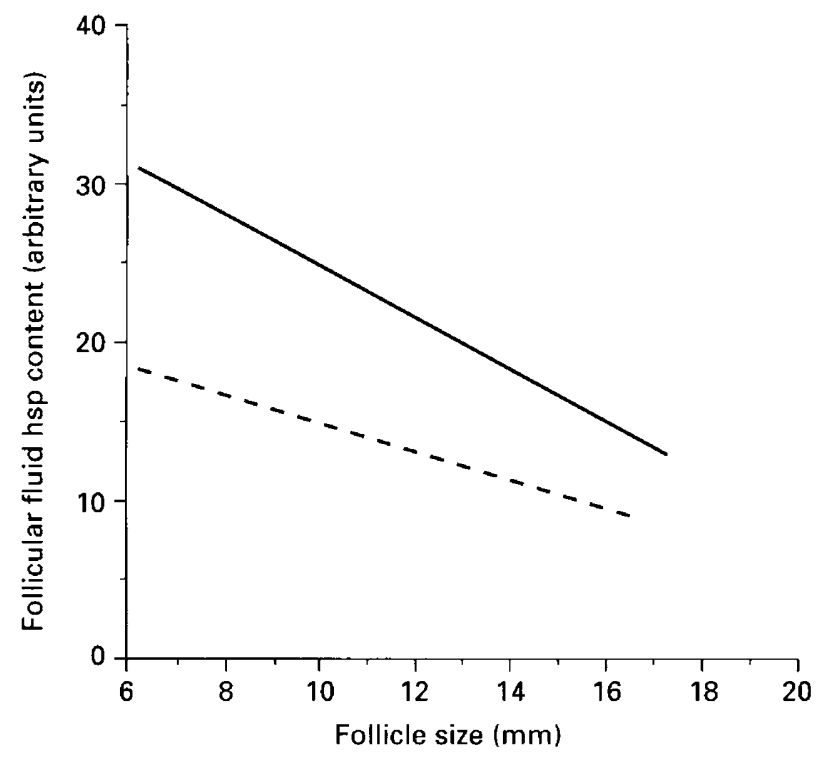

Fig. 8. Relationship between the amount of heat shock protein 90 (hsp 90) contained in the fluid of (-) healthy and (-- ) atretic bovine follicles and follicle size.

follicular fluid to be studied under physiological conditions. In some of the treatments, follicular fluid was used raw (that is, not submitted to charcoal treatment) to mimic conditions in vivo.

This study demonstrated that an aromatase inhibitor is present in bovine follicular fluid originating from dominant follicles. Whether the fluid of such follicles is obtained during the luteal phase (pool 2) or the follicular phase (pool 1) does not markedly affect its activity. This finding is in agreement with earlier reports demonstrating the inhibitory effects of inhibin-free follicular fluid in vivo (Law et al., 1992). This compound could also be responsible in part for the effect of follicular fluid observed in inhibin-immunized heifers (Wood et al., 1993). Interestingly, in the study of Wood et al. (1993), the compound was absent or present in small amounts in non-dominant follicles. A difference in the proportion of fluid from dominant and non-dominant follicles in pooled samples may explain the discrepancies between in vivo studies in which inhibitory effects of follicular fluid were observed (Law et al., 1992) and those in which such an effect was not reported (Moser et al., 1989). In addition, the inhibitory effects of bovine follicular fluid on follicular growth in sheep (Larson et al., 1991; Campbell and Scaramuzzi, 1996) indicates that its action is not species specific. In the present study, the inhibitory action of follicular fluid was observed in the absence of FSH. This suggests that the compound identified is different from those described by Rouillier et al. (1998) and Baxter et al. (1995). In contrast, similar activity has been detected in follicular fluid from pigs (Picton and Hunter, 1995).

The inhibitory activity of follicular fluid is unlikely to be related to its steroid content. Some of the experiments in this study used raw follicular fluid which contains steroids (testosterone and oestradiol). Raw fluid was used to mimic more closely the conditions in vivo and because in addition to binding steroids, charcoal treatment may also remove proteins from follicular fluid (Tsonis et al., 1983). However, the use of raw fluid makes the interpretation of results more complicated. Therefore, the testosterone and oestradiol concentrations of all biological materials were measured. The concentrations were found to be within the range observed in earlier studies of follicular fluid (Ireland and Roche, 1983a,b; McNatty et al., 1984) and ovarian venous serum (Wise et al., 1982; Ireland et al., 1984). Several findings support the conclusion that the inhibitory effect of fluid from dominant follicles is not the result of the steroids it contains (testosterone, androstenedione and oestradiol). Charcoaltreated follicular fluid was a very potent inhibitor or aromatase activity (Expt 3 ). In addition, the amounts of labelled testosterone added ( $35 \mathrm{ng}$ per follicular wall sample) are large compared with the amounts of cold testosterone resulting from addition of follicular fluid ( $5 \mathrm{ng}$ in the largest amount of fluid from dominant follicles used in the experiments). Finally, fluid from non-dominant follicles which contained four times more testosterone than fluid from dominant follicles was devoid of activity. Furthermore, in cattle, there is no evidence that oestradiol can modulate aromatase activity (Fortune and Quirk, 1988).

Although the results obtained indicate that aromatase inhibition is not related to the steroid content of follicular fluid, they did not show whether the inhibitory activity was caused by low molecular weight growth factors or higher molecular weight proteins. The most significant growth factors that have inhibitory effects on ovarian function are epidermal growth factor (EGF/TGF- $\alpha$ ), tumour necrosis factor $\alpha$ (TNF- $\alpha$ ) and interleukin 1 (IL-1) (Gougeon, 1996). However, their inhibitory effect can only be detected in the presence of FSH (Hsueh et al., 1981; Barak et al., 1992; Fukuoka et al., 1992). Because the inhibitor present in the fluid from dominant follicles is also efficient in the absence of FSH, these growth factors are unlikely to play a major role in this process. This prompted an investigation of the proteins synthesized de novo by dominant and non-dominant follicles.

Two-dimensional PAGE revealed that the overall pattern of proteins released into the incubation medium was close to that observed with sheep follicles (Driancourt et al., 1996a), with major spots at 45 and $30 \mathrm{kDa}$. Comparison of follicular fluid proteins synthesized de novo (dominant and nondominant follicles) with those detected in incubation medium revealed that a group of high molecular weight basic proteins was restricted to the samples of incubation medium, suggesting that these proteins may be of thecal origin and are too large to cross the basal membrane (Shalgi et al., 1973). In addition, quantitative differences emerged for two spots. One at $34-35 \mathrm{kDa}$ (pI 5.7) was present in higher concentrations in incubation medium than in follicular fluid, and the other at $90 \mathrm{kDa}$ (pI 5.8) was present in higher concentration in fluid from dominant follicles than in the two other media. The similarity between the physiochemical features of the latter spot and those of hsp 90 prompted a study of this protein in bovine ovarian cells and follicular fluid.

hsp 90 is constitutively expressed in somatic cells of the bovine ovarian follicles and is released into follicular fluid. In rodents, hsp 90 may be present in germinal (Curci et al., 1991) 
(a)

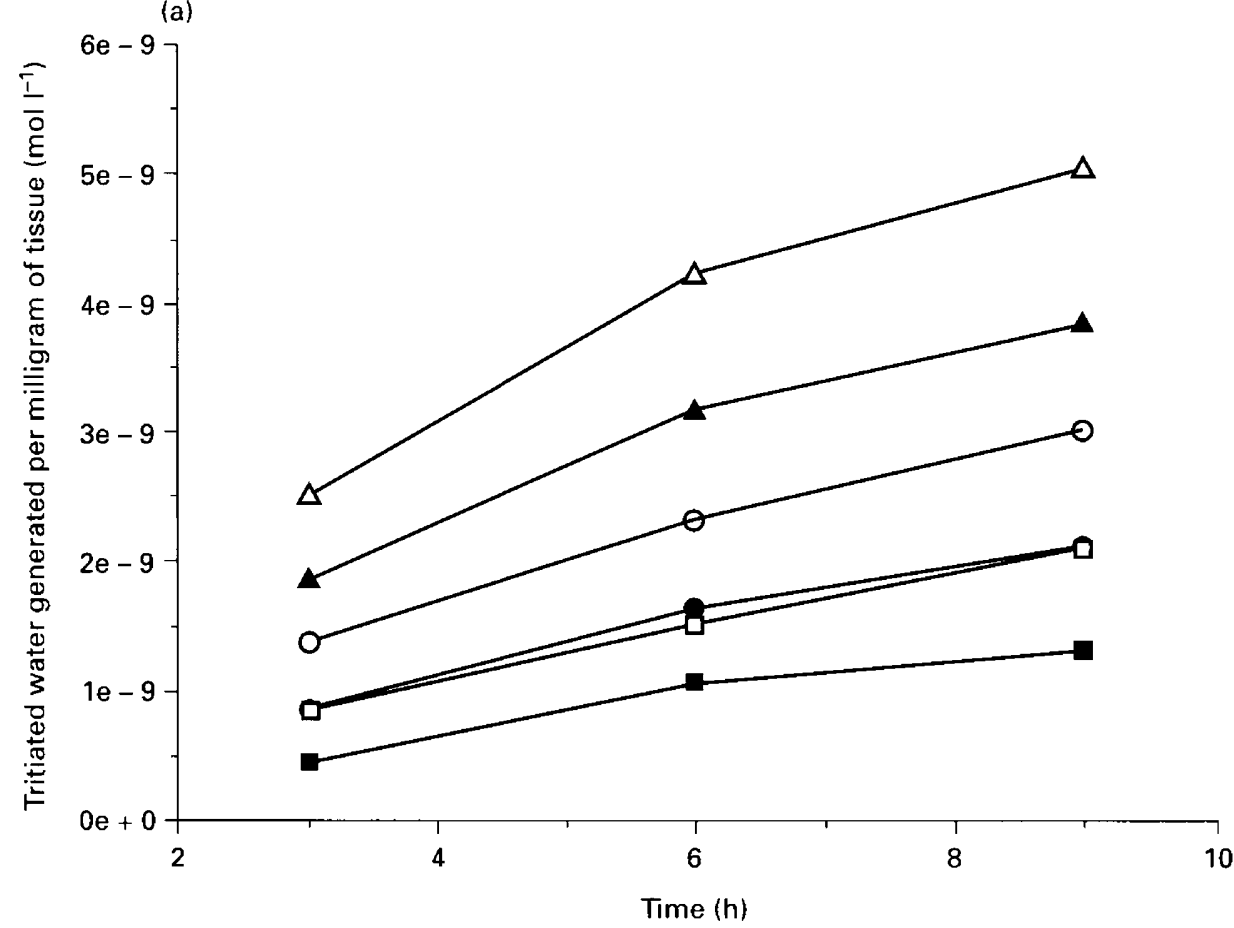

(b)

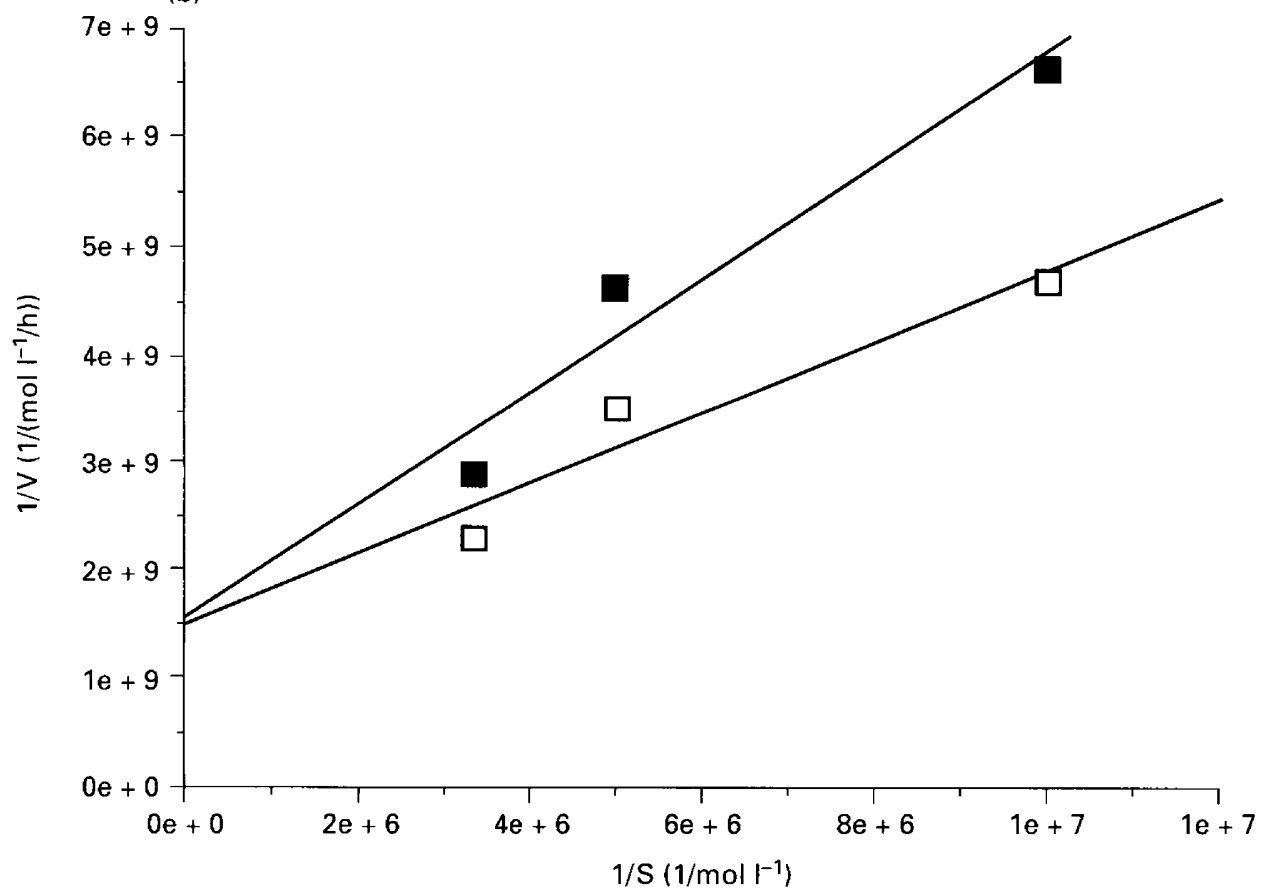

Fig. 9. (a) Effect of different amounts of $\left[{ }^{3} \mathrm{H}\right]$ testosterone on the amount of ${ }^{3} \mathrm{H}_{2} \mathrm{O}$ generated per milligram of bovine follicular wall in the presence (solid symbols) or absence (open symbols) of heat

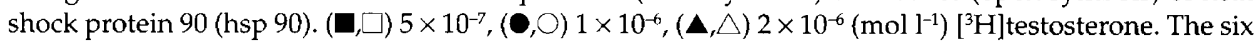
follicular wall fragments originated from the same follicle. (b) $K_{\mathrm{m}}$ and $V_{\max }$ values deduced from (a) in the ( $\square)$ presence and $(\square)$ absence of hsp 90.

and somatic cells (Ben Ze'ev and Amsterdam, 1989) of the ovary. To date, this is the first report to demonstrate that hsp 90 is also present in cattle ovaries and to establish size- and atresia-related changes in its concentration. In addition, the granulosa cells were found to be more active producers of hsp 90 than the thecal cells. Therefore, hsp 90 may be involved in follicular maturation. Other proteins involved in this process include inhibin (Sunderland et al., 1996), IGFBP (Monget and Monniaux, 1995) and tissue inhibitor of metalloproteinase 1 (TIMP-1) (Smith et al., 1996). In the present study, the density 
of labelled cells was highest in the cumulus cells, suggesting that hsp 90 also has a role in the interaction between somatic and germinal cells. The AB119 antibody detected a signal in the follicular fluid after one- and two-dimensional PAGE at a molecular weight identical to that obtained with pure hsp 90. This finding was unexpected since hsp 90 is considered to be an intracellular protein which interacts with steroid hormone receptors to form a cytoplasmic complex that inactivates the DNA binding sites of the receptor (Baulieu, 1987). However, another well characterized mitochondrial heat shock protein, hsp 60, has been identified in many locations other than mitochondria, including the cell surface (Soltys and Gupta, 1996) and even in seminal fluid (Munoz et al., 1996). In addition, translocation of hsp 90 between the cytoplasm and the nucleus has been observed (Berbers et al., 1988) suggesting that membranes may not block the movement of hsp 90 intra- and possibly intercellularly. Thus, heat shock proteins may not be restricted to intracellular sites. Detection of hsp 90-induced alterations in $K_{\mathrm{m}}$ and $V_{\text {max }}$ values of the aromatase enzyme supports the proposal that hsp 90 is associated with aromatase inhibition. In contrast, hsp 90 did not modulate the amount of aromatase in follicular wall fragments.

The inhibitory activity found in follicular fluid was not detectable in ovarian venous serum. On the basis of results from superovulation trials (Pierson and Ginther, 1988; Guilbault et al., 1991) and from FSH administration in the presence of dominant follicles (Adams et al., 1993), it has been postulated that dominant follicles produce and release compounds inimical to the growth and maturation of other follicles. These compounds would have to be secreted to affect follicles on the contralateral ovary. Therefore, they should be present in ovarian venous blood. In the present study, the activity of ovarian venous serum draining the ovary bearing the dominant follicle was compared with that of the fluid of this follicle. A range of concentrations of ovarian venous serum up to $24 \%$ did not result in inhibition of aromatase activity (Expt 5). This result indicates that the compound responsible for aromatase inhibition in the follicular fluid is not secreted and hence it is not a possible candidate to explain the inter-ovary interactions involved in follicular dominance (Pierson and Ginther, 1988; Guilbault et al., 1991; Adams et al., 1993). It is concluded that the dominant follicle does not directly affect the growth of the non-dominant follicles of its cohort, or at least that it does not do so through effects on aromatase.

In conclusion, in cattle, inter-follicle regulation does not operate through modulation of aromatase. Furthermore, somatic cells of the dominant follicle produce hsp 90 and follicular fluid contains this heat shock protein. In granulosa cells, hsp 90 may be one of the factors that modulates aromatase, while in follicular fluid, hsp 90 could act as a chaperone to protect follicular fluid proteins from proteolysis (Schneider et al., 1996).

The authors thank J. L. Touzé and his team for the excellent technical management of the heifers/cows used in this study. The help of A. Locatelli and his team with surgery is also warmly acknowledged, as is the assistance of the staff of the abattoirs in Tours and Blois. The provision of purified FSH by Y. Combarnous and N. Martinat and of aromatase antibody by G. E. Serralini was appreciated.

\section{References}

Adams GP, Kot K, Smith CA and Ginther OJ (1993) Selection of a dominant follicle and suppression of follicular growth in heifers Animal Reproduction Science 30 259-271

Barak V, Yanai P, Treves AJ, Roisman I, Simon A and Laufer N (1992) Interleukin 1: local production and modulation of human granulosa cell steroidogenesis Fertility and Sterility 58 719-725

Baulieu EE (1987) Steroid hormone antagonists at the receptor level: a role for the heat shock protein MW 90000 (hsp 90) Journal of Cell Biochemistry 35 $161-174$

Baxter G, O'Shea T, Campbell BK and Webb R (1995) Effects of bovine follicular fluid fractions which delay oestrus in sheep and cattle on proliferation and steroid production by cultured granulosa cells Journal of Reproduction and Fertility Abstract Series 15 Abstract 189

Ben Ze'ev A and Amsterdam A (1989) Regulation of heat shock protein synthesis by gonadotrophins in cultured granulosa cells Endocrinology 124 2584-2594

Berbers GAM, Kunnen R, Van Bergen en Henegonwen PMP and Van Wijk $\mathbf{R}$ (1988) Localization and quantification of hsp 84 in mammalian cells Experimental Cell Research 177 257-262

Bradford MM (1976) A rapid sensitive method for the quantification of microgram quantities of protein utilizing the principle of dye binding Analytical Biochemistry 72 248-254

Campbell BK and Scaramuzzi RJ (1996) The effect of ovarian arterial infusion of human recombinant inhibin and bovine follicular fluid on ovarian secretion by ewes with an autotransplanted ovary Journal of Endocrinology 149 531-540

Curci A, Bevilacqua A, Fiorenza MT and Mangia F (1991) Developmental regulation of heat shock response in mouse oogenesis: identification of differentially responsive oocyte classes during graafian follicle development Developmental Biology 144 362-368

Di Zerega GS, Goebelsmann U and Nakamura RM (1982) Identification of protein(s) secreted by the preovulatory ovary which suppresses the follicle response to gonadotrophins Journal of Clinical Endocrinology and Metabolism 54 1091-1096

Driancourt MA, Gormon T, Phan Thanh L and Boomarov O (1996a) Analysis by two dimensional electrophoresis of proteins secreted by sheep ovarian follicles: effects of the $\mathrm{Fec}^{\mathrm{B}}$ gene, follicle size and atresia Journal of Reproduction and Fertility 107 69-77

Driancourt MA, Paris A and Debrauwser L (1996b) Aromatase activity of ovine follicular walls. Technical validation and physiological control Reproduction Fertility Development 8 875-884

Fortune JE and Quirk SM (1988) Regulation of steroidogenesis in bovine preovulatory follicles journal of Animal Science 66 Supplement 21-8

Fortune JE, Sirois J, Turzillo AM and Lavoir M (1991) Follicle selection in domestic ruminants Joumal of Reproduction and Fertility Supplement $\mathbf{4 3}$ 187-198

Fukuoka M, Yasuda K, Fujiwara H, Kanzaki H and Mori T (1992) Interactions between interferon $\gamma$, tumour necrosis factor $\alpha$ and interleukin 1 in modulating progesterone and oestradiol production by human luteinized granulosa cells in culture Human Reproduction 7 1361-1364

Gore Langton RE and Dorrington JH (1981) FSH induction of aromatase in cultured rat granulosa cells measured by a radiometric assay Molecular and Cellular Endocrinology 22 135-151

Gougeon A (1996) Regulation of ovarian follicular development in primates: facts and hypotheses Endocrine Reviews 17 121-155

Guilbault LA, Grasso F, Lussier JG, Rouillier P and Matton P (1991) Decreased superovulatory responses in heifers superovulated in the presence of a dominant follicle Journal of Reproduction and Fertility 91 81-89

Hochereau-de Reviers MT, Copin M, Seck M, Monet-Kuntz C, Cornu C, Fontaine I, Perreau C, Elsen JM and Boomarov O (1990) Stimulation of testosterone production by PMSG injection in the ovine male: effect of breed, age and application to males carrying the F Booroola gene Animal Reproduction Science 23 21-30

Hsueh AJW, Welsh TH and Jones PBC (1981) Inhibition of ovarian and testicular steroidogenesis by epidermal growth factor Endocrinology 108 2002-2004 
Ireland JJ and Roche JF (1983a) Growth and differentiation of large antral follicles after spontaneous luteolysis in heifers: changes in concentration of hormones in follicular fluid and specific binding of gonadotropins to follicles Jotmal of Animal Science 57 157-167

Ireland JJ and Roche JF (1983b) Development of non ovulatory antral follicles in heifers: changes in steroids in follicular fluid and receptors for gonadotropins Endocrinology 112 150-156

Ireland JJ, Fogwell RL, Oxender WD, Awes K and Cowley JL (1984) Production of estradiol by each ovary during the estrous cycle of cows Journal of Animal Science 59 764-771

Lahteenmaki $P$, Lobo R, Marrs R, Gibbons WE, Nakamura $K$ and Di Zerega GS (1982) Characterization of porcine granulosa cells by isopycnic gradient centrifugation Biology of Reproduction 27 663-640

Larson GH, Mallory DS, Dailey RA and Lewis PE (1991) Gonadotropin concentrations, follicular development and luteal function in pituitary stalk sectioned ewes treated with bovine follicular fluid Journal of Animal Science 69 4104-4111

Law AS, Baxter G, Logue DN, O'Shea T and Webb R (1992) Evidence for the action of bovine follicular fluid factor(s) other than inhibin in suppressing follicular development and delaying oestrus in heifers journal of Reproduction and Fertility $96603-616$

Ledwitz Rigby F (1983) Follicular fluid stimulation of estrogen secretion by immature porcine granulosa cells Molecular and Cellular Endocrinology 29 213-222

Lees Miller SP and Anderson CW (1989) Two human $90 \mathrm{kDa}$ heat shock proteins are phosphorylated in vivo at conserved serines that are phosphorylated in vitro by casein kinase II Journal of Biological Chemistry 264 2431-2437

McNatty KP, Heath DA, Henderson KM, Lun S, Hurst PR, Ellis LM, Montgomery GW, Morrison L and Thurley DC (1984) Some aspects of thecal and granulosa cell function during follicular development in the bovine ovary Journal of Reproduction and Fertility 72 39-53

Meduri G, Vu Hai Luu Thi MT, Jolivet A and Milgrom E (1992) New functional zonation in the ovary as shown by immunohistochemistry of luteinizing hormone receptor Endocrinology 131 366-373

Meduri G, Vu Hai MT, Jolivet A, Takenori S, Komimami S, Driancourt MA and Milgrom E (1996) Comparison of cellular distribution of LH receptors and steroidogenic enzymes in the porcine ovary journal of Endocrinology 148 435-446

Michaelis L (1922) Die Wasserstoffionkonzentration Springer Verlag, Berlin

Monget P and Monniaux D (1995) Growth factors and the control of folliculogenesis Journal of Reproduction and Fertility Supplement 49321-333

Moser MT, Garverick HA, Smith MF and Younquist RS (1989) Effect of bovine follicular fluid and follicle stimulating hormone on follicular growth in unilaterally ovariectomized prepubertal heifers Journal of Dairy Science $\mathbf{7 2}$ 2170-2178

Munoz MG, Jeremias J and Witkin SS (1996) The $60 \mathrm{kDa}$ heat shock protein in human semen: relationship with antibodies to spermatozoa and chlamydia trachomatis Human Reproduction 11 2600-2603

Picton HM and Hunter MG (1995) Purification and characterization of a porcine follicular fluid protein which inhibits aromatase activity in granulosa cells in vitro. Journal of Endocrinology Supplement 14796

Pierson RA and Ginther OJ (1988) Follicular populations during the estrous cycle in heifers. III. Time of selection of the ovulatory follicle Animal Reproduction Science 16 81-95

Roberts RM, Baumbach GA, Buhi WC, Denny JB, Fitzgerald LA, Babelyn SF and Horst MN (1984) Analysis of membrane polypeptides by two dimensional polyacrylamide gel electrophoresis. In Molecular and Chemical Characterization of Membrane Receptors pp 61-113 Eds CJ Wenter and LC Harrison. AR Liss, New York

Rouillier P, Matton P, Sirard MA and Guilbault LA (1998) Effect of bovine follicular fluid from healthy and atretic follicles on follicle-stimulating hormone-induced production of estradiol by bovine granulosa cells cultured in vitro. Journal of Animal Science 76 1172-1177
Saumande J (1990) Culture of bovine granulosa cells in a chemically defined serum free medium. The effect of insulin and fibronectin on the responses to FSH Journal of Steroid Biochemistry and Molecular Biology 18 189-196

Savio JD, Keenan L, Boland MP and Roche JF (1988) Pattern of growth of dominant follicles during the oestrous cycle of heifers Journal of Reproduction and Fertility $83663-671$

Scaramuzzi RT and Downing JA (1995) The in vivo effects of fibroblast growth factor and epidermal growth factor on the secretion of oestradiol, androstenedione and progesterone by the autotransplanted ovary of the ewe Journal of Endocrinology 146 301-311

Schneider C, Sepp-Lorenzino L, Nimmesgern E, Overfelli O, Dan Shefsky S, Rosen N and Harte FU (1996) Pharmacologic shifting of a balance between protein refolding and degradation mediated by hsp 90 Proceedings National Academy of Sciences USA 93 14536-14 541

Shalgi R, Kraicer P, Rimon A, Pinto M and Soferman N (1973) Proteins of human follicular fluid: the blood-follicular barrier Fertility and Sterility 24 429-434

Sirois J and Fortune JE (1988) Ovarian follicular dynamics during the estrous cycle in heifers monitored by real time ultrasonography Biology of Reproduction 39 308-317

Sirois J, Kimmich TL and Fortune JE (1989) Developmental changes in steroidogenesis by equine preovulatory follicles. Effects of equine LH, FSH and CG Endocrinology $1272423-2430$

Smith GW, Juengel JL, McIntush EW, Youngquist RS, Garverick HA and Smith MF (1996) Ontogenesis of messenger RNA encoding tissue inhibitor metalloproteinases 1 and 2 within bovine periovulatory follicles and luteal tissue Domestic Animal Endocrinology 13 151-160

Soltys BJ and Gupta RS (1996) Immunoelectron microscopic localization of the $60 \mathrm{kDa}$ heat shock chaperonin protein (hsp 60) in mammalian cells Experimental Cell Research 222 16-27

Sunderland SJ, Knight PG, Boland MP, Roche JF and Ireland JJ (1996) Alterations in intrafollicular levels of different molecular forms of inhibin during development of follicular and luteal phase dominant follicles in heifers Biology of Reproduction 54 453-462

Terqui M (1978) Contribution à l'étude des oestrogènes chez la brebis et la truie DSc Thesis, Paris University

Thatcher WW, Driancourt MA, Terqui M and Badinga L (1991) Dynamics of ovarian follicular development in cattle following hysterectomy and during early pregnancy Domestic Animal Endocrinology 8 223-234

Tsonis CG, Quigg H, Lee VWK, Leversha $L_{r}$, Trouson AO and Findlay JK (1983) Inhibin in individual ovine follicles in relation to diameter and atresia Journal of Reproduction and Fertility 67 83-90

Ui M, Shimonaka M, Shimasaki S and Long N (1989) An insulin like growth factor binding protein in ovarian follicular fluid blocks follicle-stimulating hormone-stimulated steroid production by ovarian granulosa cells Endocrinology 125 912-916

Westhof G, Westhof KF, Ahmad N and Di Zerega GS (1989) Alteration of follicular steroid secretion and thecal morphology after in vitro exposure of individual pig follicles to follicle regulatory protein Journal of Reproduction and Fertility 87 133-140

Wise TH, Caton D, Thatcher WW, Rami Lehrer A and Fields MJ (1982) Androstenedione, dehydroepiandrosterone and testosterone in ovarian vein plasma and androstenedione in peripheral arterial plasma during the bovine oestrous cycle Journal of Reproduction and Fertility 66 513-518

Wood SC, Glencross RG, Bleach ECL, Lovell R, Beard AJ and Knight PG (1993) The ability of steroid free bovine follicular fluid to suppress FSH secretion and delay ovulation persists in heifers actively immunized against inhibin Journal of Endocrinology 136 137-148

Ying SY, Becker A, Ling N, Ueno N and Guillemin R (1986) Inhibin and beta type transforming growth factor have opposite modulating effects on the FSH-induced aromatase activity of cultured rat granulosa cells Biochemical and Biophysical Research Communications 136969-975 